\title{
EFEKTIFITAS EKSTRAK SAUROPUS ANDROGYNUS (DAUN KATUK) DAN EKSTRAK MORINGA OLEIFERA LAMK (DAUN KELOR) TERHADAP PROSES PERSALINAN, PRODUKSI KOLOSTRUMDAN PROSES INVOLUSI UTERI IBU POSTPARTUM
}

\author{
Setiawandari ${ }^{1}$, Istiqomah ${ }^{2}$ \\ 1 Program Studi DIII Kebidanan, Fakultas IImu Kesehatan, \\ Universitas PGRI Adi Buana Surabaya \\ ${ }^{2}$ Bidan Praktek Mandiri Istiqomah Surabaya \\ Email : setiawandari@unipasby.ac.id
}

\begin{abstract}
ABSTRAK
Kelahiran sang buah hati adalah moment bahagia yang dinantikan oleh semua orang tua. Seorang ibu yang mampu memberikan ASI secara eksklusif (0-6 bulan) memberikan arti kebahagiaan tersendiri bagi seorang ibu. Tetapi tidak jarang, hal ini terkendala dengan produksi ASI ibu yang belum keluar pada hari-hari pertama menyusui. Hal inilah yang membuat orang tua khawatir tidak bisa memenuhi kebutuhan nutrisi bayinya diawal kehidupannya, sehingga memutuskan untuk memberikan susu formula.

Tujuan penelitan adalah untuk mengetahui efektifitas ekstrak Sauropus Androgynus (daun katuk) dan ekstrak Moringa oleifera Lamk (daun kelor) terhadap proses persalinan, produksi kolostrum dan proses involusi uteri ibu postpartum.

Metode yang digunakan dalam pengambilan sampel adalah menggunakan metode total sampling. Dengan sampel penelitian adalah semua ibu hamil demgan usia kehamilan 37-40 minggu yang melahirkan normal di Praktik Mandiri Bidan. Jenis penelitian ini adalah true eksperiment dengan desain penelitian posttest with control group design.

Hasil penelitian adalah tidak ada pengaruh pemberian ekstrak daun katuk dan ekstrak daun kelor terhadap proses persalinan dengan nilai $p=0,457>\alpha=0,05$. Pemberian daun katuk lebih efektif dibanding daun kelor dalam hal mempercepat pengeluaran produksi kolostrum dengan nilai $p=0,026<\alpha=0,05$. Dan tidak ada perbedaan antara pemberian daun katuk dengan daun kelor terhadap proses involutio uteri dengan nilai $p=0,552>\alpha=0,05$ (24jam), $p=0,905>\alpha=0,05$ (48jam), $p=0,719>\alpha=0,05(72 j a m)$.

Kesimpulan adalah ekstrak daun katuk dan ekstrak daun kelor bisa diberikan pada ibu hamil trimester III dan tidak menimbulkan komplikasi proses persalinan, ekstrak daun katuk lebih efektif dalam meningkatkan produksi ASI dan tidak ada pengaruh terhadap proses involusi uteri.

Kata Kunci : Ekstrak Sauropus Androgynus (Daun Katuk), Ekstrak Moringa oleifera Lamk (Daun Kelor), Proses Persalinan, Produksi Kolostrumdan Proses Involusi Uteri Ibu Postpartum
\end{abstract}

\section{PENDAHULUAN}

Indonesia adalah negara yang mempunyai keunikan dan kekayaan hayati, salah satunya adalah kaya akan tumbuhtumbuhan yang dapat digunakan sebagai bahan obat tradisional atau herbal. Tidak semua obat tradisional merugikan bagi kesehatan khususnya bagi kesehatan ibu hamil dan menyusui. Telah banyak dilakukan penelitian-penelitian terkait dengan hal tersebut, misalnya bahan tanaman yang berkhasiat untuk meningkatkan produksi ASI bagi ibu menyusui. Seperti yang tertulis dalam Permenkes RI Nomor 6 Tahun 2016 tentang Formularium obat herbal asli Indonesia untuk meningkatkan produksi ASI ibu diantaranya adalah daun katuk, biji klabet dan daun torbangun. Walaupun demikian, sebenarnya masih banyak tanaman yang 
telah diteliti yang dapat meningkatkan produksi ASI tetapi belum tertulis dalam Permenkes RI Nomor 6 Tahun 2016, antara lain : daun buah pepaya, daun kelor, daun murbei, kacang hijau, lampes, adas manis, bayam duri, bidara upas, blustru, dadap ayam, jinten hitam pahit, nangka, patikan kebo, pulai, temulawak, dan turi (Istiqomah, SBT. 2014). Sejalan dengan hasil penelitian Sa'roni, dkk (2004) berjudul Effectiveness of the Sauropus Androgynus (L.) Merr Leaf Extract in Increasing Mother's Breast Milk Production, menyatakan pemberian ekstrak daun katuk pada ibu melahirkan dan menyusui dapat meningkatkan produksi ASI sebanyak $66,7 \mathrm{ml}$ atau $50,7 \%$, menurunkan subyek kurang ASI sebanyak 12,5\%.

Profil Kesehatan Indonesia 2014 menyebutkan bahwa cakupan pemberian ASI eksklusif sebesar $52,3 \%$, hal tersebut belum mencapai $80 \%$ dari apa yang ditargetkan. Upaya yang dilakukan pemerintah dalam meningkatkan derajat kesehatan pada ibu hamil dan menyusui pada khsususnya telah dilaksanakan diantaranya dengan penerapan teknologi tepat guna. Penerapan praktis tampak pada digalakkannya budidaya tanaman toga (tanaman obat keluarga) yang banyak dimanfaatkan sebagai bahan untuk mengobati penyakit atau keluhan kesehatan yang terjadi dalam keluarga dengan harga yang murah, terjangkau, tidak menimbulkan efek samping dan efek ketergantungan. Salah satunya adalah tanaman toga daun katuk, daun kelor, klabet atau daun pepaya yang banyak tumbuh di halaman rumah untuk meningkatkan produksi ASI.

Masalah yang ditemukan adalah banyak ibu-ibu hamil dan menyusui yang tinggal dikota dan bekerja, sulit untuk mendapatkan tanaman tersebut di halaman rumah atau pasar tradisional. Peran herbalis dalam menciptakan ekstrak tanaman herbal telah banyak membantu ibu dan keluarga dalam memenuhi kebutuhan bayinya di 1000 hari pertama kehidupan anaknya. Peran penting tenaga kesehatan dalam memberikan konseling tentang ASI eksklusif, kapan dan bagaimana memulai merawat payudaranya, sehingga tidak ada alasan lagi bagi ibu untuk tidak menyusui bayinya di 24 jam pertama melahirkan dengan alasan ASI belum keluar.
Dengan adanya masalah tersebut diatas, peneliti ingin mengetahui kapan sebaiknya ekstrak daun katuk (Sauropus Androgynus) dan ekstrak daun kelor (Moringa oleifera Lamk) diberikan pada ibu. Selain itu juga pemberian intervensi yang dilakukan pada beberapa hari menjelang persalinan apakah lebih efektif daripada pemberian intervensi yang dilakukan setelah ibu masuk pada masa nifas dalam hal keluarnya produksi kolostrum.

Penelitian ini bertujuan untuk mengetahui efektifitas ekstrak Sauropus Androgynus (daun katuk) dan ekstrak Moringa oleifera Lamk (daun kelor) terhadap proses persalinan, produksi kolostrum dan proses involusi uteri ibu postpartum.

\section{METODE PENELITIAN}

Jenis penelitian ini menggunakan true eksperiment dengan desain penelitian posttest with control group design. Metode yang digunakan dalam pengambilan sampel adalah menggunakan metode total sampling. Variabel independent penelitian ini adalah Ekstrak Sauropus Androgynus (Daun Katuk) dan Ekstrak Moringa oleifera Lamk (Daun Kelor), sedangkan variable dependentnya adalah proses persalinan, produksi kolostrum dan proses involusi uteri. Data dianalisis menggunakan Uji Independent Samples $T$.

Penelitian dilakukan di Bidan Praktek Mandiri Istiqomah, dengan sampel penelitian ibu hamil trimester III usia kehamilan 37-40 minggu yang melakukan kunjungan Ante Natal Care dan berencana melahirkan di BPM Istiqomah sebanyak 20 orang. Kemudian responden ibu hamil tersebut di random untuk dibagi menjadi 2 kelompok. Kelompok pertama diberikan ekstrak daun katuk 3x1 kapsul (114 mg) selama 10 hari menjelang hari perkiraan persalinan dan 10 hari setelah persalinan. Kelompok kedua diberikan ekstrak daun kelor 2 x 1 (500 mg) selama 10 hari menjelang hari perkiraan persalinan dan 10 hari setelah persalinan. Kemudian masing-masing responden diobservasi bagaimana proses persalinannya, hari keberapa keluar produksi kolostrumnya (sebelum atau sesudah melahirkan) dan bagaimana proses involusi uterinya. 


\section{HASIL PENELITIAN}

Tabel 1.1 Proses Persalinan, Produksi Kolostrum dan Proses Involusi Uteri Pada Responden Ekstrak Daun Katuk

\begin{tabular}{|c|c|c|c|c|c|c|}
\hline \multirow[t]{3}{*}{ No } & \multirow[t]{3}{*}{$\begin{array}{c}\text { Proses } \\
\text { PersalinanKala I-III }\end{array}$} & \multicolumn{2}{|c|}{ Kolostrum keluar hr ke : } & \multicolumn{3}{|c|}{$\begin{array}{c}\text { Involusi Uteri } \\
\text { cm diatas symphisis }\end{array}$} \\
\hline & & Sebelum Partus & Sesudah Partus & & & \\
\hline & & \multicolumn{2}{|c|}{ (jam) } & $\begin{array}{c}24 \\
\text { jam }\end{array}$ & 48 jam & $\begin{array}{l}72 \\
\text { jam }\end{array}$ \\
\hline 1 & 2 jam 15 menit & 72 & & 12 & 8 & 7,5 \\
\hline 2 & 14 jam 21 menit & & 48 & 12 & 10,5 & 9 \\
\hline 3 & 2 jam 55 menit & & 48 & 11 & 10 & 9 \\
\hline 4 & 6 jam 15 menit & & 24 & 13 & 9 & 8 \\
\hline 5 & 5 jam 40 menit & 72 & & 12 & 9 & 8,5 \\
\hline 6 & 3 jam 45 menit & & 48 & 13 & 11 & 10 \\
\hline 7 & 18 jam & & 48 & 13 & 11,5 & 10 \\
\hline 8 & 15 jam 25 menit & 72 & & 11 & 9,5 & 7 \\
\hline 9 & 3 jam 35 menit & & 24 & 12 & 9 & 7,5 \\
\hline 10 & 7 jam 51 menit & & 48 & 12 & 10 & 8 \\
\hline
\end{tabular}

Sumber : Data Primer

Tabel 1.2Proses Persalinan, Produksi Kolostrum dan Proses Involusi Uteri Pada Responden Ekstrak Daun Kelor

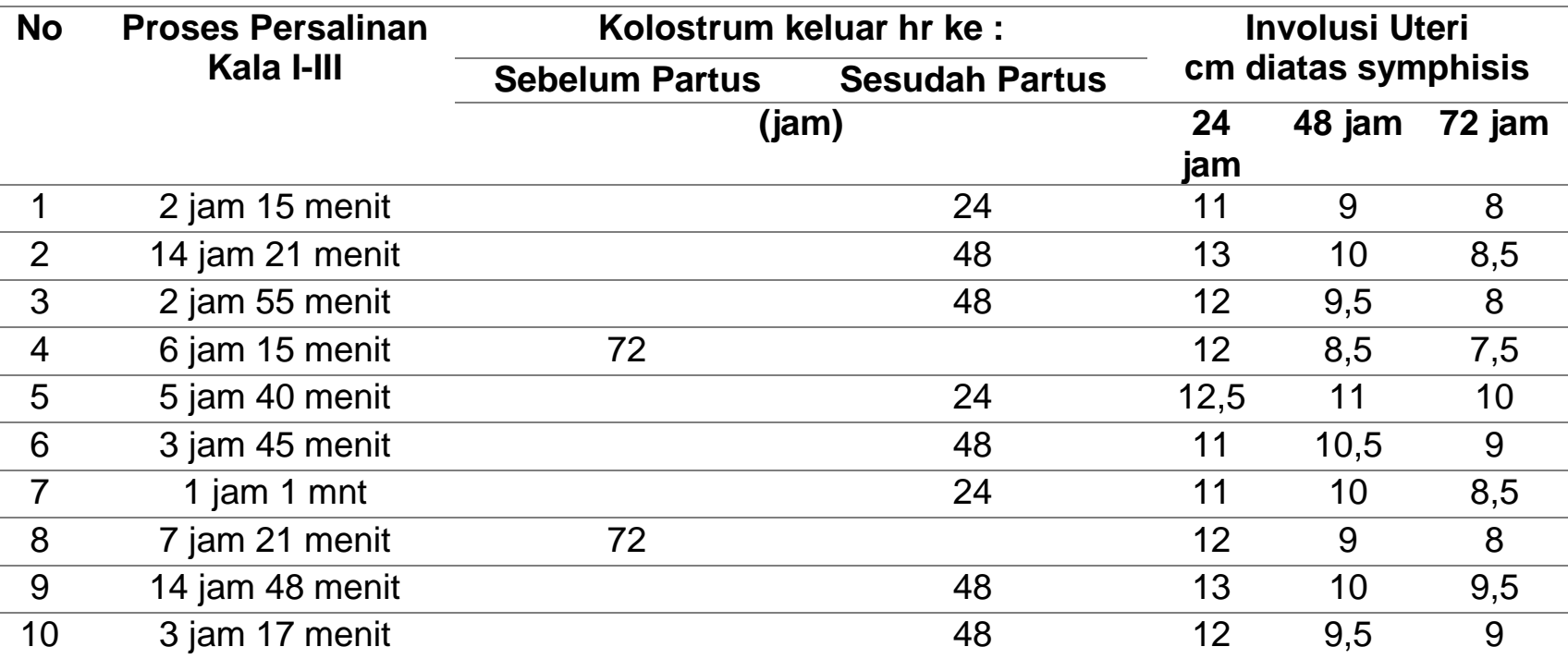

Sumber : Data Primer

Berdasarkan hasil uji Independent Samples Test, didapatkan $p=0,457>\alpha=0,05$ yang artinya tidak ada pengaruh pemberian ekstrak daun katuk dan ekstrak daun kelor pada ibu hamil trimester tiga usia kehamilan 37-40 minggu terhadap proses persalinan. Hasil penelitian pada 20 responden kelompok ibu hamil usia kehamilan 37-40 minggu yang mendapatkan ekstrak daun katuk dan ekstrak daun kelor pada 10 hari sebelum persalinan dan 10 hari sesudah persalinan, tidak mengalami komplikasi pada proses persalinannya.

Hasil hasil uji Independent Samples Testnilai $\quad p=0,026<\alpha=0,05 y$ yng berarti pemberian daun katuk lebih efektif dibanding daun kelor dalam hal mempercepat pengeluaran produksi kolostrum.lbu hamil yang keluar kolostrumnya 3 hari sebelum melahirkan sebanyak 4 orang, 2 hari sebelum melahirkan 2 orang. Dan 4 orang ibu keluar produksi kolostrumnya setelah 24 jam postpartum. Sedangkan pada kelompok ibu 
hamil usia kehamilan 37-40 minggu yang mendapatkan ekstrak daun kelor pada 10 hari sebelum persalinan dan 10 hari sesudah persalinan, tidak mengalami komplikasi pada proses persalinannya. Ibu hamil yang keluar kolostrumnya 3 hari sebelum melahirkan sebanyak 2 orang. Sedangkan 3 orang keluar produksi kolostrumnya 24 jam postpartum dan 5 orang 48 jam postpartum.

Pada proses involusi uteri, didapatkan hasilnilai $\quad p=0,552>\alpha=0,05 \quad$ (24jam), $p=0,905>\alpha=0,05 \quad$ (48jam), $p=0,719>\alpha=0,05$ (72jam), tidak ada perbedaan antara pemberian daun katuk dengan daun kelor pada proses involutio uteri postpartum. Pada proses involusi uteri kedua kelompok tidak mengalami komplikasi sub involusi. Pada hari pertama postpartum, involusi uteri berjalan sesuai dengan tahapan involusi yaitu 12-13 $\mathrm{cm}$ atau 1 jari dibawah pusat. Pada hari ke-2 postpartum, setengah dari responden (50\%) mengalami involusi lebih cepat dari tahapan involusi hari ke-2 (10-11 cm). Dan setengahnya lagi, involusi sesuai dengan tahapan involusi. Pada hari ke-3 postpartum, sebagian besar ibu postpartum (60\%) mengalami involusi uteri lebih cepat dari tahapan involusi normal $(9-10 \mathrm{~cm})$.

\section{PEMBAHASAN \\ Pengaruh Ekstrak Sauropus Androgynus (Daun Katuk) dan Ekstrak Moringa oleifera Lamk (Daun Kelor) terhadap Proses Persalinan}

Hasil penelitian didapatkan tidak ada pengaruh pemberian ekstrak daun katuk dan ekstrak daun kelor pada ibu hamil trimester tiga usia kehamilan 37-40 minggu terhadap proses persalinan. Dari 20 ibu hamil trimester tiga yang diberikan ekstrak daun katuk dan daun kelor, satu orang dilakukan rujukan dengan indikasi medis yaitu ketuban pecah premature lebih dari 24 jam. Sedangkan 19 responden penelitian mengalami proses persalinan yang normal, tidak ditemukan komplikasi seperti ketuban mekonial, kala I memanjang, kala II memanjang dan perdarahan kala III. Begitu juga dengan penilaian Apgar Scor pada bayi baru lahir, tidak ditemukan bayi baru lahir dengan asfiksia.

Proses persalinan pada setiap ibu hamil berbeda-beda, tetapi pada dasarnya ada tiga tahapan yang akan dilalui yaitu Kala
I persalinan atau yang disebut dengan kala pembukaan, Kala II persalinan atau disebut dengan kala pengeluaran dan kala III persalinan atau kala pengeluaran plasenta. Lamanya kala I untuk primigravida 12,5 jam dan untuk multigravida 7 jam 20 menit. Hal tersebut dikarenakan mekanisme membukanya serviks antara primigravi dan dan multigravida berbeda. Pada primigravida, ostium uteri akan membuka terlebih dahulu, sehingga serviks akan mendatar dan menipis, kemudian ostium ekternum membuka. Sedangkan pada multigravida ostium uteri internum dan ostium uteri eksternum serta penipisan dan pendataran serviks terjadi pada saat yang sama. Hal inilah yang menyebabkan waktu berlangsungnya kala I pada primigravida lebih lama dari pada multigravida. Kala II pada primigravida berlangsung selama \pm 120 menit, sedangkan pada multigravida diharapkan tidak lebih dari 60 menit. Persalinan kala III atau kala pengeluaran pada primigravida dan multigravida berlangsung hampir sama, yaitu \pm 10 menit. Pada penelitian ini sebanyak 20 orang, 3 diantaranya pengalami proses persalinan yang lebih dari yang diperkirakan > 14 jam. Dan satu orang mengalami komplikasi ketuban pecah premature 24 jam sehingga dilakukan rujukan ke institusi kesehatan yang lebih tinggi.

Lancarnya proses persalinan dipengaruhi oleh beberapa faktor, yaitu : passage (jalan lahir), power, pasange, psikis dan penolong. Faktor kekuatan atau power yang mendorong janin keluar terdiri dari : kontraksi otot uterus (his), kontraksi otot-otot uterus, kontraksi diafragma pelvis, dan ketegangan serta ligamentous action terutama ligamentum rotundum. Kuat lemahnya his bisa dipengaruhi oleh pemberian stimulasi dan nutrisi. Stimulasi pijat oksitosin dan stimulasi putting susu adalah beberapa contoh intervensi stimulasi yang bisa diberikan pada ibu bersalin yang mengalami gangguan inersia uteri hipotonik (his lemah). Sedangkan tanaman rumput Fatimah yang jika pemberiannya berlebihan mempunyai efek steroid bisa merangsang hipotalamus posterior untuk menstimulasi hormon oksitosin sehingga menyebabkan his yang tidak terkoordinir atau hipertonik. Begitu juga daun kelor, senyawa bioaktif pada 
kedua tanaman tersebut menyebabkan daun katuk dan daun kelor memiliki sifat farmakologis yaitu antimikroba, antijamur, antihipertensi, antihyperglikemik, antitumor, antikanker, anti-inplamasi (Toma \& Deyno, 2014) dalam Syarifahet al (2015).

Mengkonsumsi daun katuk dan daun kelor adalah sebagai salah satu tradisi dari masyarakat kita oleh ibu menyusui yang dipercaya dapat meningkatkan produksi ASI. Dengan semakin berkembangnya jaman, maka tanaman ini agak sulit ditemukan di daerah perkotaan, sehingga beberapa perusahaan melakukan pengekstrakan daun katuk dan daun kelor. Di beberapa institusi kesehatan, kedua ekstrak ini diberikan kepada ibu segera setelah selesai melahirkan, dikarenakan beberapa alasan yaitu diantaranya, bahwa mengkonsumsi ekstrak herbal hampir sama dengan mengkonsumsi jamu-jamuan, sehingga dipercaya akan dapat menjadikan suatu komplikasi tersendiri bagi ibu hamil dan akan menganggu jalannya proses persalinan. Oleh karena itu pemberian daun kelor pada ibu hamil, masih diperdebatkan. Beberapa sumber menyebutkan bahwa mengkonsumsi daun kelor dianjurkan pada ibu hamil, tetapi beberapa diantaranya mengatakan untuk menghindari mengkonsumsi daun kelor saat kehamilan. Beberapa bahan kimia yang terkandung didalam tanaman kelor (akar, kulit dan bunga kelor) dapat menyebabkan kontraksi rahim, sehingga tidak disarankan dikonsumsi pada ibu hamil trimester I. Mengkonsumsi daun kelor berlebihan juga dapat menimbulkan efek samping diare (http://www.sehatinstan.com). Daun kelor juga dipercaya menyebabkan rasa sakit pada proses persalinan dikarenakan daun kelor mengandung getah yang pedis (kompasiana, 2017).

Dari sumber yang menganjurkan ibu hamil untuk mengkonsumi daun kelor, hal tersebut dikarenakana kandungan zat besi pada daun kelor bisa menyembuhkan anemia pada ibu hamil, selain itu mengkonsumsi daun kelor saat kehamilan dapat mengurangi masalah sulit tidur, hipertensi, menambah kalsium, menjaga level gula darah dan sebagai antioksidan. Berdasarkan hasil penelitian Hermansyah, dkk (2013), bahwa pemberian ekstrak daun kelor berhubungan dengan peningkatan berat badan berkontribusi terhadap peningkatan lingkar lengan atas ibu hamil namun tidak meningkatkan kadar HB. Sejalan dengan hasil penelitian Lucia, dkk (1997) dalam Sa'roni (2004) tentang Uji Teratogenik Daun Katuk pada Mencit Hamil, bahwa daun katuk tidak toksik dan tidak menimbulkan kecacatan pada janin. Menurut Paget, SE, dkk (1964) dalam Sa'roni (2004) tentang hasil penelitian efek farmakologi ekstrak daun katuk dosis $631,6 \mathrm{mg} / \mathrm{kg}$ berat badan menunjukkan efek laktogoum pada tikus. Apabila dosis tersebut diekstrapolasikan pada manusia berdasarkan luas permukaan tubuh dan kepekaan menjadi sekitar 900mg/hari pada manusia.

Kebiasaan masyarakat dalam mengolah daun katuk sebagai suatu cara untuk meningkatkan produksi ASI dilakukan dengan cara menjadikan daun katuk sebagai sayur bening, proses pemasakan ini sebenarnya berfungsi juga untuk menghilangkan sifat anti protozoa yaitu membunuh racun yang terkandung pada daun katuk tersebut. Dan untuk mengurangi efek samping dari daun katuk selain dengan dimasak adalah dengan mengkonsumsi daun katuk mentah dalam jumlah yang sedikit (maksimal 50 gram per hari) dan tidak mengkonsumsi daun katuk secara terus menerus selama lebih dari 3 bulan.

\section{Pengaruh Ekstrak Sauropus Androgynus (Daun Katuk) dan Ekstrak Moringa oleifera Lamk (Daun Kelor) terhadap Produksi Kolostrum}

Dari hasil penelitian menyatakan pemberian ekstrak daun katuk lebih efektif dibanding ekstrak daun kelor dalam hal mempercepat pengeluaran produksi kolostrum.

Masyarakat Indonesia sudah sejak ratusan tahun yang lalu telah memiliki tradisi memanfaatkan tanaman dari lingkungan sekitarnya. Manfaat tanaman bagi kesehatan telah banyak diteliti sebagai alternatif obatobatan yang mempunyai kandungan bahan kimia. Beberapa tradisi masyarakat yang sampai dengan saat ini masih dilakukan, diantaranya mengkonsumsi tanaman yang dipercaya mampu untuk meningkatkan produksi ASI, diantaranya daun katuk dan daun kelor. Daun katuk dan daun kelor kini dapat dikonsumsi dengan mudah, dibuat 
dalam bentuk kapsul siap minum yang mengandung $100 \%$ ekstrak daun hijau yang diproses secara hygienis tanpa tambahan bahan apapun guna menjaga khasiat dari daun katuk dan daun kelor.

Hasil penelitian yang dikutip oleh Warta Puslitbang Perkebunan (2014) mengatakan bahwa daun katuk dikenal sebagai tanaman perangsang ASI, karena mengandung sterol (dengan turunanya fitosterol) dan polifenol yang dapat meningkatkan kadar hormon prolaktin untuk memproduksi ASI, merangsang hormon desitosin untuk memacu pengeluaran dan pengaliran ASI, serta memiliki efek laktogogum yang dapat meningkatkan jumlah dan mutu ASI karena mengandung zat yang bersifat fitosterol $446 \mathrm{mg} / 100 \mathrm{~g}$. Demikian juga dengan tanaman kelor, di Indonesia tanaman kelor disebut sebagai pohon ajaib karena memiliki banyak manfaat bagi manusia, diantaranya untuk ibu menyusui. Sama halnya dengan daun katuk, daun kelor mengandung senyawa fistosterol yang berfungsi meningkatkan dan melancarkan produksi ASI (efek laktogogum). Kandungan nutrisi yang luar biasa pada kelor, dimanfaatkan tidak hanya untuk ibu hamil dan menyusui, tetapi juga untuk mengatasi masalah malnutrisi pada balita. Dalam daun kelor mengandung Fe $5,49 \mathrm{mg} / 100 \mathrm{~g}$, dan fitosterol yaitu sitosterol $1,15 \% / 100 \mathrm{~g}$ dan stigmasterol $1,52 \% / 100 \quad \mathrm{~g}$ yang dapat merangsang produksi ASI (Warta Puslitbang Perkebunan, 2014).

Sejalan dengan hasil penelitian Sudarto (1990)dalam Santoso (2013) bahwa daun katuk berperan dalam menyuburkan ASI sehubungan dengan peranan laktagogum dalam merefleksi prolaktin, yaitu refleks yang merangsang alveoli untuk memproduksi susu. Refleks dihasilkan dari reaksi antara prolaktin dan hormon adrenal steroid dan tiroksin. Saroni et al. (2004) menemukan bahwa pemberian ekstrak daun katuk pada ibu menyusui bayinya dengan dosis $3 \times 300 \mathrm{mg} /$ hari selama 15 hari dapat meningkatkan produksi ASI 50,7\%.

Semua makanan dan minuman dapat menjadi booster ASI bagi ibu, selama ibu percaya dan tersugesti bahwa makanan dan minuman tersebut bisa meningkatkan produksi ASI. Karena itulah peneliti berpendapat bahwa efek booster ASI dapat berbeda-beda pada setiap orang. Seorang ibu yang suka mengkonsumsi kacang hijau akan merasa produksi ASI nya meningkat dan banyak. Tetapi efek ini belum tentu sama dengan ibu lainnya, terutama jika ibu tersebut tidak menyukai kacang hijau, ibu akan merasa tidak nyaman sehingga dapat menurunkan produksi ASInya. Dari beberapa penelitian mengindikasikan bahwa laktogogum bekerja melalui dua cara. Yang pertama dengan menstimulasi hormon prolaktin, dan yang kesua dengan meningkatkan rasa percaya diri ibu. Sehingga tidak ada booster ASI tertentu yang lebih direkomendasikan dibandingkan dengan booster ASI lainnya, karena walaupun booster ASI dapat membantu dalam beberapa kasus untuk mengatasi masalah kasus produksi ASI yang sedikit, tetapi booster ASI bukan satu-satunya solusi ketika produksi ASI ibu berkurang. Walaupun ibu mengkonsumsi booster ASI, tetapi jika ibu mengalami gangguan psikologis atau ibu tidak sedini mungkin berusaha memberikan ASI kepada bayinya, dan ibu tidak melakukan perawatan pada payudaranya serta tidak mengkonsumsi makanan dengan nutrisi seimbang maka fungsi booster ekstrak daun katuk dan ekstrak daun kelor tidak akan maksimal. Laktagogum hanya bekerja ketika ASI sering dikeluarkan atau diisap oleh bayi. Oleh karena itu laktagogum dalam ekstrak daun katuk atau daun kelor lebih efektif untuk meningkatkan produksi ASI ketika ibu menyusui sering memberikan ASInya pada bayi. Hal ini dikarenakan isapan bayi merupakan salah satu faktor pemicu produksi ASI dengan memberikan sinyal ke otak untuk melepaskan hormon yang diperlukan untuk produksi ASI.

\section{Pengaruh Ekstrak Sauropus Androgynus (Daun Katuk) dan Ekstrak Moringa oleifera Lamk (Daun Kelor) terhadap Proses Involusi Uteri Ibu Postpartum}

Hasil penelitian tidak ada perbedaan antara pemberian daun katuk dengan daun kelor pada proses involutio uteri. Involusi uteri adalah proses kembalinya uterus ke keadaan sebelum hamil, dimulai segera setelah plasenta keluar akibat kontraksi otototot polos uterus (Bobak, 2012). Pada akhir tahap ketiga persalinan, uterus berada di garis tengah, kira-kira $2 \mathrm{~cm}$ di bawah 
umbilicus. Dalam waktu 12 jam, tinggi fundus mencapai kurang lebih $1 \mathrm{~cm}$ diatas umbilicus. Dalam beberapa hari kemudian, perubahan involusi berlangsung dengan cepat. Fundus turun kira-kira 1-2 $\mathrm{cm}$ setiap 24 jam. Enam hari postpartum fundus normal akan berada pertengahan antara umbilikus dan simpisis pubis, dan uterus tidak bisa dipalpasi pada hari ke-9 postpartum. Kembalinya rahim ibu ke bentuk semula dipengaruhi oleh beberapa faktor, diantaranya inisiasi menyusui dini dan mobilisasi aktif. Pada saat ibu menyusui, terjadi rangsangan ke hipofisis posterior sehingga dikeluarkannya oksitosin yang berfungsi untuk meningkatkan kontraksi otot polos di sekitar jaringan alveoli kelenjar ASI sehingga ASI dikeluarkan. Oksitosin juga merangsang otot rahim untuk berkontraksi sehingga mempercepat proses involusi uteri. Menurut Sulistyawati (2009) dalam Sari et al (2011) kontraksi memiliki peranan yang sangat penting dalam involusi uterus. Kontraksi dan retraksi otot uterus akan mengurangi suplai darah ke uterus sehingga akan membantu mengurangi bekas luka tempat implantasi plasenta dan mengurangi perdarahan serta mempercepat pengeluaran lokia.

Ekstrak daun katuk dan ekstrak daun kelor secara tidak langsung mempengaruhi proses involusi uteri. Kandungan laktogoum pada daun katuk dan daun kelor membantu meningkatkan produksi ASI ibu. Peningkatan produksi ASI akan mendorong ibu untuk lebih sering menyusui bayinya. Dengan seringnya bayi menyusu hal ini akan menyebabkan terjadinya umpan balik positif dimana hipofise posterior akan memproduksi oksitosin lebih banyak sehingga mempengaruhi proses involusi berjalan cepat dengan cara mengompresi pembuluh darah dan membantu proses hemostasis. Proses ini akan membantu mengurangi perdarahan sehingga lochea pada ibu nifas akan berkurang dan menurunkan tinggi fundus uteri. Sejalan dengan hasil penelitian Suwanti (2014) tentang kandungan laktogogum pada daun ubi jalan, mempunyai hubungan yang bermakna dengan percepatan involusi uteri, responden yang mengkonsumsi daun ubi jalar, sebagian besar mengalami pengeluaran lochea normal. Hasil penelitian Sari (2011) menyatakan bahwa pemberian ekstrak dan fraksi daun katuk dapat mempengaruhi involusi uterus tikus, dimana bobot uterus tikus mencapai bobot normal pada 5 hari postpartum dan semakin mengecil pada 10 hari postpartum.

Beberapa hal dapat mempengaruhi proses involusi uteri yaitu mobilisasi dini, status gizi, menyusui, usia dan parietas. Daun katuk dan daun kelor mempunyai kandungan gizi yang dibutuhkan oleh ibu postpartum, salah satunya adalah kandungan zat besi dan vitamin $C$ yang dapat meningkatkan daya tahan tubuh untuk pulih kembali kekeadaan sebelum hamil. Kehilangan darah pada saat melahirkan, akan menyebabkan ibu postpartum jatuh dalam kondisi anemia, sehingga diperlukan suplemen makanan atau zat gizi seimbang. Menurut Yahya et al (1992) dalam Santoso (2013), dalam $100 \mathrm{~g}$ daun katuk mentah dikandung zat besi $6,25 \mathrm{mg}$, direbus dengan air $3 \mathrm{mg}$, dikukus $5,84 \mathrm{mg}$ dan direbus dengan santan 3,12 mg. sedangkan kandungan vitamin $\mathrm{C}$ dalam $100 \mathrm{~g}$ daun katuk mentah dikandung $197,48 \mathrm{mg}$, direbus $71,55 \mathrm{mg}$, dikukus menjadi $41,1 \mathrm{mg}$ dan direbus dengan santan menjadi $77,36 \mathrm{mg}$. Sehingga ekstrak daun kelor dan ekstrak daun kelor bisa digunakan sebagai alternative pengganti atau diberikan bersamaan dengan vitamin zat besi.

\section{SIMPULAN DAN SARAN}

Hasil penelitian ini menunjukkan bahwa tidak ada pengaruh pemberian ekstrak daun katuk dan ekstrak daun kelor pada ibu hamil trimester tiga usia kehamilan 37-40 minggu terhadap proses persalinan. Ada pengaruh pemberian ekstrak daun katuk terhadap produksi kolostrum, yaitu lebih cepat produksi kolostrum keluar pada ibu yang mengkonsumsi ekstrak daun katuk dari pada ibu yang mengkonsumsi ekstrak daun kelor. Ekstrak daun katuk dan ekstrak daun kelor juga tidak mempengaruhi proses involusi uteri.

Berdasarkan kesimpulan penelitian, disarankan kepada tenaga kesehatan untuk selalu memberikan support kepada ibu hamil untuk mengkonsumsi nutrisi yang menunjang kelancaran proses menyusui selain dengan tetap memberikan ibu pendidikan kesehatan tentang Inisiasi Menyusu Dini dan mobilisasi aktif pasca melahirkan. 
Ucapan terima kasih disampaikan kepada Lembaga Penelitian dan Pengabdian Pada Masyarakat Universitas PGRI Adi Buana Surabaya yang telah mendanai penelitian ini.

\section{DAFTAR PUSTAKA}

Alegantia, dkk. Kualitas Ekstrak Etanol 70\% Daun Kelor (Moringa oleifera Lamk) dalam Ramuan Penambah Asi. Pusat Biomedis dan Teknologi Dasar Kesehatan. Pusat Teknologi Terapan dan Epidemologi Klinik. Badan Libangkes Kemenkes RI.

Bobak(2012).Buku Ajar Keperawatan Maternitas. Jakarta.EGC

(http://www.sehatinstan.com/2017/09/3bahaya-dan-efek-samping-daunkelor.html. Diunggah tanggal 10 Agustus 2017

https://www.kompasiana.com/tatikbahar/pant angan-makanan-bagi-ibu-hamil (hartatik bahar, 2011). Diunggah tanggal 10 Agustus 2017

https://manfaat.co.id/manfaat-daun-keloruntuk-ibu-hamil.Diunggah tanggal 10 Agustus 2017

Hermansyah, dkk. 2014. Ekstrak Daun Kelor Terhadap Peningkatan Asupan Dan Berat Badan Ibu Hamil Pekerja Sektor Informal. Jurnal IImu Kesehatan Masyarakat. Volume 5. 03 November 2014. FKM.Unhas.

Kamariyah, N. Pengaruh Fraksi Ekstrak Daun Sauropus Androgynus (L.) Merr (Katuk) Terhadap Kadar Prolaktin Tikus Menyusui \& Sel Neuraglia Anak Tikus. Jurnal Stikes Yarsis. Surabaya

Kristina, dkk. 2014. Pemanfaatan Tanaman Kelor (Moringa oleifera) Untuk Meningkatkan Produksi Air Susu Ibu. Warta Penelitian dan Pengembangan Tanaman Industri, Volume 20 Nomor 3.

Kementerian kesehatan Republik Indonesia.2015. Profil Kesehatan Indonesia 2014. Jakarta.Kemenkes RI.

Lusiana et al.Pengaruh Kombinasi Ekstrak Daun Katuk (Sauropus Androgynus(L.) Merr.) dan Domperidon Terhadap Involusi Uterus Mencit Menyusui. http://repository.maranatha.edu/12533/10/ 1110057. Journal.pdf. Diunggah 20 November 2017
Mutiara, T. 2011. Uji Efek Pelancar ASI Tepung Daun Kelor (Moringa oleifera (Lamk)) Pada Tikus Putih Galur Wistar. Laporan Hasil Penelitian Disertasi Doktor Tahun Anggaran 2011. Universitas Brawijaya. Malang

Nindiyaningrum NA. Pengaruh Pemberian Ekstrak Daun Katuk Terhadap Produksi Asi Pada Ibu Post Partum. Jurnal Stikes telogorejo Semarang.

Sa'roni, dkk. 2004. Effectiveness of the Sauropus Androgynus (L.) Merr Leaf Ektract in Increasing Mother's Breast Milk Production. Media Litbang Kesehatan Volume XIV Nomor 3 Tahun 2004

Sugiyono. 2009. Metodelogi Penelitian Kuantitatif Kualitatif dan $R \quad \& D$. Cetakanke-8. Bandung: Alfabeta

Syarifah, A et al. 2015. Kandungan Nutrisi dan Sifat Fungsional Tanaman Kelor (Moringa oleifera). Buletin Pertanian Perkotaan Volume 5 Nomor 2. Balai Pengkajian Teknologi Pertanian Jakarta

Santoso, U. 2013. Katuk, Tumbuhan Multi Khasiat. ISBN. 978-602-9071-12-2. Fakultas Pertanian Unib

Sari et al. 2011. Pengaruh Pemberian Ekstrak dan Fraksi Daun Katuk (Sauropus androgynus (L.) Meer) terhadap Involusi Uterus Tikus (Rattus norvegicus)

http://repository.ipb.ac.id/handle/1234567 89/52336 Diunggah 20 November 2017

Suwanti, E. 2014. Kecepatan Involusi Uteri pada Ibu Nifas Dengan Konsumsi Daun Ubi Jalar. Jurnal IImu Kesehatan vol.3 nomor $1 . \quad \mathrm{http}: / / j u r n a l . p o l t e k k e s-$ solo.ac.id/index.php/Int/article/view/77/67

Wahyuni, RB. 2017. Pengaruh Variasi Pengolahan Dan Pemanasan Ulang Terhadap Kandungan Zat Gizi Dan Bioavailabilitas Mineral Daun Kelor. Tesis. IPB

Warta Puslitbang Perkebunan (Puslitbangbun) Vol. 20 No. 3, 2014. Pemanfaatan tanaman Kelor (Moringa oleifera) Untuk Meningkatkan Produksi Air Susu Ibu. http://perkebunan.litbang.pertanian.go.id/ $? p=11232$ 